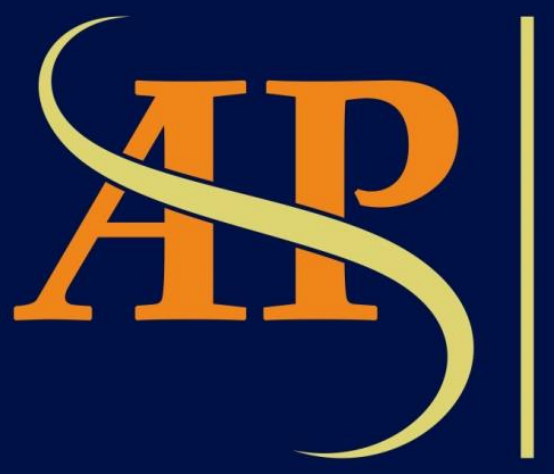

JURNAL ASIA PACIFIC STUDIES

Journal of International Relations Study Program Faculty of Social and Political Sciences Universitas Kristen Indonesia

Volume 4 | Number 1 | January- June 2020 


\title{
PROSES SEKURITISASI PANDEMI SARS-COV-2 (COVID-19) DI INDONESIA SERTA IMPLIKASINYA TERHADAP HUBUNGAN LUAR NEGERI INDONESIA
}

\author{
Rasyid Arifin \\ Magister Hubungan Internasional, Fakultas Ilmu Sosial dan Ilmu Politik, Universitas Indonesia, Gedung \\ Nusantara II Lt. 2, Depok, Jawa Barat 16424 Indonesia. \\ Arifinrasyid13@gmail.com
}

\begin{abstract}
The SARS-CoV-2 or Covid-19 virus pandemic in Indonesia underwent a process of securitization in an effort to eliminate the threat. Securitization is the solution faced by Indonesia Covid-19. This study describes the Covid19 securitization process in Indonesia. The question of this research is how is the Covid-19 securitization process in Indonesia? The variables used in this study are securitization actors, Speech Acts, existential threats, object referent, and extraordinary actions to explain the Covid-19 securitization process in Indonesia. This study uses a qualitative method.
\end{abstract}

Keywords: Securitization, Covid-19, Indonesia, International Relation

\begin{abstract}
Abstrak
Pandemi virus SARS-CoV-2 atau Covid-19 di Indonesia mengalami proses sekuritisasi dalam upaya untuk mengeliminasi ancaman. Sekuritisasi menjadi solusi yang dilakukan indonesia menghadapi Covid-19. Kajian ini menggambarkan proses sekuritisasi Covid-19 di Indonesia. Pertanyaan kajian ini bagaimana proses sekuritisasi Covid-19 di Indonesia? Variabel-variabel yang dipakai pada kajian ini aktor sekuritisasi, Speech Act, existential threat, refrent object, dan extraordinary measure dapat menjelaskan proses sekuritisasi Covid-19 di Indonesia. Kajian ini menggunakan metode kualitatif.
\end{abstract}

Kata Kunci : Sekuritisasi, Covid-19, Indonesia, Hubungan Internasional 


\section{Pendahuluan}

Studi hubungan internasional terhadap ancaman yang datang terhadap referen objek juga berkembang seiring dengan perkembangan ancaman-ancaman pada zaman sekarang. Ancaman yang datang kepada negara bukan hanya berasal dari ancaman tradisional atau militer melainkan ancaman-ancaman non-militer atau yang dikenal dengan ancaman nontradisional. Ancaman non-tradisional bisa berupa masalah kesehetan, lingkungan, terorisme, pangan, organisasi kejahatan trans-nasional dan lain-lain. Dewasa ini dunia tengah dihadapkan dengan keamanan atau keberlangsungan dari manusia itu sendiri. Dunia dihadapkan dengan keamanan individu yang kasusnya memengaruhi negara hingga sistem internasional. Negara dihadapkan dengan sebuah evolusi virus yang mengancam siapapun.

\subsection{Latar Belakang Penelitian}

Dunia saat ini tengah diuji dengan ujian yang sangat sulit untuk diselesaikan. Seluruh negara dalam sistem internasional kesulitan dalam menghadapi pandemi yang terjadi serentak di seluruh dunia, baik itu pemerintahan negara-negara maju seperti Amerika Serikat, Tiongkok, dan lain-lain ataupun pemerintahan negara-negara berkembang seperti Indonesia. Tidak ada satupun pemerintah yang siap dengan pandemi yang terjadi di dunia saat ini seperti apa yang dikatakan oleh Presiden terpilih Indonesia ke-7 Joko Widodo pada cnbcindonesia dalam situasi seperti ini, tidak ada satupun dari 213 negara yang betul-betul siap (Asamara 2020). Pandemi Covid-19 bermula untuk pertama kalinya pada tanggal 31 Desember 2019 ketika Tiongkok melaporkan kepada World Health Organization (WHO) penemuan virus yang berjenis pneumonia ${ }^{l}$ yang penyebabnya belum diketahui di Kota Wuhan, Provinsi Hubei, Tiongkok (Baskara 2020). Kasus Covid-19 sebenarnya sudah dimulai pada tanggal 17 November 2019 berdasarkan data pemerintah yang diberitakan oleh South China Morning Post (SCMP) setidaknya 266 orang terpapar Covid-19 pada tahun 2019 dan 381 orang terpapar Covid-19 pada hari pertama tahun 2020 (Ma 2020). Dunia dihadapkan dengan pandemi yang menyerang negara manapun baik itu negara maju ataupun negara berkembang. Per tanggal 8 Juni 2020 total orang yang terpapar Covid-19 sebanyak 7.015.079 (tujuh juta lima belas ribu tujuh puluh sembilan) orang di seluruh dunia (John Hopkins University and Medicine 2020). Negara-negara saling menguatkan dalam menghadapi pandemi Covid-19 (Ramdhan 2020). Ketidaksiapan 213 negara dalam menghadapi pandemi Covid-19 memaksa negara-negara saling membantu dan membuat kebijakan-kebijakan untuk memutus rantai penyebaran pandemi Covid-19.

Dalam sejarah Indonesia dua dekade terakhir, Indonesia dua kali terserang pandemi dalam sekala besar yaitu pada tahun 2003 yaitu pandemi Severe Acute Respiratory Syndrome (SARS) yang juga memaksa WHO mengumumkan SARS sebagai Ancaman globa pada 15 Maret 2013 (Kementerian Kesehatan Republik Indonesia 2003), dan pandemi Avian Influenza (flu burung) pada 2012 Indonesia tercatat sebagai negara dengan kasus terbanyak dalam menghadapi pandemi flu burung (BBC 2012). Reaksi pemerintah Indonesia dinilai penulis sudah cukup cepat dalam menghadapi pandemi yang terjadi di Indonesia. Terhitung sejak pelaporan adanya pandemi pada 31 Desember 2019 oleh Tiongkok kepada WHO Indonesia telah memberlakukan pemeriksaan Covid-19 pada 135 titik di bandar udara pada tanggal 18 Januari 2020 (Kementrian Luar Negeri Indonesia 2020) dalam upaya memutus rantai penyebaran Covid-19 melalui impor penyakit. Penulis berpendapat bahwa kebijakan

\footnotetext{
${ }^{1}$ Pneunomia adalah infeksi pada salah satu atau kedua paru-paru yang disebabkan oleh bakteri, virus dan jamur. Infeksi mengakitbatkan peradangan pada kantong-kantong udara di paru-paru yang menyebabkan gangguan pernafasan.
} 
pemerintah Indonesia dalam menghadapi Covid-19 sudah baik terlepas banyak kritikankritikan yang datang baik itu dari masyarakat ataupun media kepada pemerintah dalam penanganan Covid-19.

Permasalahan kesehatan yang dikarenakan oleh pandemi Covid-19 berubah menjadi isu keamanan seperti yang dijelaskan oleh Mayor Jendral Sisriadi pada laman detik hakikatnya pandemi menjadi masalah keamanan nasional, dan Covid-19 tidak semata-mata masalah kesehatan (Ernes 2020). Ketika masalah ekonomi menyentuh masyarakat akar rumput, maka ini berkaitan erat dengan masalah perut, jika hal itu dibiarkan maka akan timbul masalah-masalah keamanan yang lebih besar (Ernes 2020). Desakan dari Sisriadi bukan tanpa alasan negara lain seperti Venuzuela, Afrika Selatan, Itali dan lain-lain terjadi kerusuhan akibat kelaparan diakibatkan lockdown yang dilakukan negara masing-masing (Muhaemin 2020; Utomo 2020; JPNN 2019). Kebijakan yang dilakukan oleh pemerintahan negara-negara lain dalam menghadapi pandemi Covid-19 dinilai penulis sangat rasional dengan harapan untuk memutus rantai penyebaran pandemi Covid-19 pemerintah menerapkan Lockdown wilayah bahkan negara, namun ketidakmampuan ekonomi masyarakat menjadi ancaman yang datang dari dalam negara itu sendiri.

Berbagai negara memiliki aturan masing-masing dalam menangani permasalahan yang dihadapi oleh negaranya. Negara-negara maju mempunyai fasilitas-fasilitas yang mencukupi untuk menangani ancaman yang datang dari luar ataupun dari dalam negara. Indonesia sebagai negara berkembang sebenarnya memiliki fondasi yang sangat bagus untuk menghadapi ancaman yang datang baik itu ancaman tradisional ataupun ancaman nontradisional. Pembukaan Undang-Undang Dasar (UUD) menyatakan adanya tanggung jawab nasional terhadap warga negara. Adapun keterlibatan militer dalam hal ini adalah turunnya pihak kepolisian dan intel dalam penanganan Covid-19 (Taher 2020; CNN 2020). Polisi juga diturunkan untuk membubarkan keramaian yang diharapkan dapat memutus atau setidaknya menghambat pertumbuhan Covid-19 (Wareza 2020). Indonesia sebenarnya memiliki UU karantina kesehatan UU 6/2018 pada pasal 9,49,dan 93 yang berisi 1) Setiap orang wajib mematuhi penyelenggaraan kekarantinaan kesehatan 2) Setiap orang berkewajiban ikut serta dalam penyelenggaraan kekarantinaan kesehatan. Dalam pasal 49 1) dalam rangka melakukan tindakan mitigasi faktor risiko di wilayah pada situasi kedaruratan kesehatan masyarakat dilakukan karantina rumah, karantina wilayah, karantina rumah sakit, atau pembatasan sosial berskala besar oleh pejabat karantina kesehatan 2) karantina rumah sakit, atau pembatasan sosial berskala besar sebagaimana dimaksud pada ayat (1) harus didasarkan pada pertimbangan epidemiologis besarnya ancaman, efektifitas, dukungan sumber ekonomi, sosial budaya, dan keamanan. 3) karantina wilayah dan pembatasan sosial berskala besar sebagaimana dimaksud pada ayat (1) ditetapkan oleh menteri dan pada pasal 93 yang berisi setiap orang yang tidak mematuhi penyelenggaraan kekarantinaan kesehatan sebagaimana dimaksud dalam pasal 9 ayat (1) dan/atau menghalang-halangi penyelenggaraan kekarantinaan kesehatan sehinga menyebabkan kedaruratan kesehatan masyarakat dipidana dengan pidana penjara paling lama 1 (satu) tahun dan/atau pidana paling banyak Rp 100.000.000,00 (seratus juta rupiah). Dengan adanya UU terlihat jelas pada prakteknya militer yang menjadi aktor yang lebih penting tanpa mengesampingkan petugas kesehatan yang berdiri di garda terdepan dalam penanganan Covid-19 di Indonesia. Hal ini menjadikan puzzle penelitian yang menarik untuk dibahas.

\subsection{Rumusan Masalah Penelitian}

Permasalahan pandemi Covid-19 di Indonesia menarik untuk dianalasis, termasuk carut-marutnya cara penyelesaian atau penanggulangan pandemi Covid-19 di Indonesia. Tumpang-tindih keputusan pemerintah dan satuan gugus tugas (SATGAS) menambah 
kekacauan baik itu di lingkup pemerintahan maupun masyarakat. Sekuritisasi yang dilakukan oleh pemerintahan-Indonesia terkait dengan pemutusan rantai penyebaran Covid-19 menarik untuk dianalisis karena itu penulis memiliki pertanyaan penetian sebagai berikut Bagaimana proses sekuritisasi Covid-19 di Indonesia?

\subsection{Maksud dan Tujuan Penelitian}

Rumusan masalah penelitian ini bertujuan untuk menggambarkan proses sekuritisasi yang dilakukan oleh Indonesia terhadap ancaman yang datang dari pandemi Covid-19. Kemudian dilanjutkan dengan pemaparan sudut pandang penulis mengenai apa yang dilakukan Indonesia dalam menghadapi ancaman pandemi Covid-19. Serta implikasi dari sekuritisasi yang dilakukan oleh pemerintahan Indonesia dalam menanggulangi pandemi Covid-19 terhadap hubungan luar negeri Indonesia.

\subsection{Signifikansi Penelitian}

Dari signifikansi teoritik, penelitian ini diharapkan dapat menyumbangkan dalam memperluas dan menambah literatur atau bahan bacaan kepada proses sekuritisasi Covid-19 yang terjadi di Indonesia. Dan tujuan dari sekuritisasi yang dilakukan suatu negara terhadap suatu pandemi yang terjadi di negara tersebut dalam hal ini objek dari penelitian ini adalah Indonesia. Bagaimana negara mengemas isu pandemi dari suatu isu kesehetan menjadi isu keamanan.

\section{Kajian Pustaka dan Kerangka Penelitian}

\subsection{Kajian Pustaka}

Sebagai topik yang hangat banyak kajian yang membahas tentang Covid-19. Topik Covid-19 dibahas dari berbagai persepsi baik pengaruh Covid-19 terhadap sistem internasional ataupun tata cara penanganan atau respon dari negara bagaimana cara negara menghadapi pandemi yang datang. dari semua bahan bacaan yang berhubungan dengan Covid-19 penulis mengelompokan bacaan-bacaan yang dinilai penulis kepada beberapa kategori agar mempermudah penulis dalam menarik kesimpulan apa yang menjadi pembahruan dari penelitian yang dilakukan penulis. Ketegori yang pertama merupakan kategori saran dan solusi dari literatur (Zahrotunnimah 2020; Kitchin 2020; Lisbet 2020; Yunus and Rezki 2020; Indriya 2020; Martha 2020; Gronvall 2020; Mukharom and Aravik 2020; Telaumbanua 2020), kategori yang kedua adalah dampak dari Covid-19 (Syawfi 2020; Hanoatubun 2020; Gronvall 2020; Purwanto et al. 2020; Ozili and Arun 2020; Haripin 2020). Kedua kategori kajian pustaka dinilai penulis cukup untuk menjadi dasar dari pada penelitian.

Kategori yang pertama yang berkaitan dengan Covid-19 berkaitan tentang saran dan solusi baik itu terhadap pemerintah ataupun dunia internasional. Gronvall pada menuliskan langkah kerja sama atau kolaborasi secara diplomatis yang menghasilkan ketertarikan publik dinilai cukup tepat sebagai solusi menghadapi SARS-CoV-2 atau Covid-19, serta perlunya menambah keterampilan dalam bidang sains biologi di sektor publik, termasuk area-area yang tidak langsung terlibat didalam didalam sektor keuangan, menajemen, dan penelitian biologi(Gronvall 2020, 84). Indriya menambahkan solusi lain dalam menghadapi permasalahan pandemi Covid-19 adalah konsep yang ada dalam kitab suci agama Islam yaitu Tafakkur, tafakkur sendiri dapat diartikan sebagai tindakan berpikir untuk menjembatani persepsi dan konsepsi dari kehidupan dunia ini ke kehidupan akhirat, dan dari makhluk ke 
Penciptanya, yaitu Allah SWT (Indriya 2020, 211). Indriya juga menyebutkan empat solusi dari taffakur yaitu yang pertama karantina, yang kedua bersabar, yang ketiga berbaik sangka, dan yang terakhir banyak berdoa. Rob Kitchin juga menambahkan dalam tulisannya untuk memutus rantai penyebaran Covid-19 ada baiknya menggunakan teknologi pengintaian (Kitchin 2020). Lisbet dalam artikelnya menuliskan bagaimana seharusnya dunia internasional merespon pandemi yang terjadi saat ini dengan diberlakukannya kerja sama internasional dari negara-negara dalam usaha pengembangan vaksin Covid-19 yang diharapkan mempercepat proses pembuatan dari Covid-19. Jessica Martha memberikan saran bagaimana pemanfaatan dari diplomasi publik oleh Indonesia dapat berperan besar untuk menstabilkan kondisi dari Indonesia sendiri, langkah-langkah diplomasi publik seperti make sense of event, networking, dan craft message and event oleh Claudia Auer dan Eva-Karin Olsson dapat memberikan solusi untuk menyetabilkan keadaan atau suasana dari Indonesia (Martha 2020).

Sama seperti Indriya Mukharom dan Aravik memberikan saran terhadap penanganan pandemi Covid-19 yang mana bercermin kepada kebijakan Nabi Muhammad SAW dalam menangani pandemi yang terjadi pada zaman Nabi Muhammad SAW, yaitu dengan memberlakukan lockdown dan social distancing dan menyegerakan penelitian terkait dengan anti virus atau vaksin dari Covid-19 (Mukharom and Aravik 2020). Senada dengan Mukharom dan Aravik, Yunus dan Annisa juga menilai kebijakan lockdown merupakan langkah yang paling tepat diberlakukan oleh pemerintah dalam menghadapi pandemi Covid19. Sedikit memiliki kesamaan dengan penulis sebelumnya Dalinama Telaumbanua menambahkan penerapan 5 aturan pemerintah yang tercantum dalam UU nomor 6 tahun 2018 tentang karantina kesehatan yang nilai sebenarnya memiliki kegunaan dalam mengantisipasi keadaan darurat kesehatan yang pada akhirnya memaksa adanya karantina wilayah dari Indonesia sendiri (Telaumbanua 2020). Dan yang terakhir merupakan langkah-langkah yang sudah dilakukan oleh pemerintah Indonesia baik itu dari tingkatan yang paling atas yaitu presiden hingga kepala daerah bagaimana langkah-langkah taktis dari tingkat yang paling atas dinilai Zahrotunnimah sudah cukup baik berupa strategi komunikasi yang digunakan yang isinya memiliki kemiripan dengan pendekatan yang dilakukan oleh Jessica yaitu diplomasi publik (Zahrotunnimah 2020). Dari kategori pertama dapat ditarik kesimpulan bahwa solusi yang ditawarkan oleh penulis-penulis terdahuli memiliki kesamaan yaitu dengan memberlakukan karantina wilayah atau lockdown dan memberlakukan social distancing serta menerapkan diplomasi publik guna meredakan atau menstabilkan suasana atau keadaan yang terjadi di Indonesia ataupun negara lain, serta penerapan kerja sama Internasional dan penggunaan teknologi dinilai sebagai solusi dari pandemi yang dihadapi dunia saat ini. Kekurangan dari kategori pertama tidak menjelaskan proses yang harus dilakukan oleh pemerintah bagaimana karantina wilayah dapat dilakukan siapa aktor-aktor yang terlibat bagaimana pemerintah meyakinkan masyarakat bahwa negara memerlukan karantina wilayah untuk memutus rantai penyebaran Covid-19.

Katergori yang kedua dalam tinjauan pustaka yang dinilai penulis berkaitan dengan Covid-19 adalah dampak yang diberikan oleh pandemi Covid-19 baik itu pada Sistem Internasional, Amerika Serikat sebagai negara maju dan Indonesia sebagai negara berkembang. Pada level sistem internasional Syawfi dalam tulisannya berargumen bahwa terjadi pergeseran yang diakibatkan oleh pandemi Covid-19 yang mengakibatkan pola hubungan yang bersifat positive sum yang didasarkan kepada interdependensi, institusionalisme, multilateralisme, dan sistem demokrasi menjadi pola hubungan yang lebih mengarah kepada zero sum game dimana negara semakin memperkuat dirinya dan saling berkompetisi dengan negara lain (Syawfi 2020). Pada tatanan global Covid-19 juga mempengaruhi ekonomi global seperti yang tulis oleh Burhanuddin dan Abdi bahwa Covid19 menunjukkan bahwa sektor ekonomi juga bisa terdampak bukan hanya sektor kesehatan 
dan budaya saja yang terkena dampak dari Covid-19, hal ini dibuktikan dengan menurunnya pertumbuhan ekonomi dari seluruh negara di dunia(Burhanuddin and Abdi 2020). Literatur berikutnya masih pada level sistem internasional oleh Ozili dan Arun yang menyebutkan kebijakan social distancing pada aktivitas ekonomi dan indeks pasar saham yang mengalami penurunan, hal ini disebabkan oleh penambahan hari dari lockdown yang dilakukan oleh pemerintah dan pelarangan atau pembatasan perjalanan keluar negeri yang dilakukan oleh berbagai negara yang menyebabkan efek spillover kepada ekonomi dunia (Ozili and Arun 2020). Sedangkan dampak dari Covid-19 pada negara maju seperti Amerika Serikat berhubungan langsung dengan keamanan nasional, yang dapat diidentifikasi dari kekuranganan jumlah logistik dan kemampuan untuk mengidentifikasi orang-orang yang terpapar Covid-19 yang menyebabkan menurunnya kesadaran dari masyarakat yang mengakibatkan banyaknya nyawa yang hilang (Gronvall 2020).

Selanjutnya pengaruh Covid-19 pada Indonesia yang dijelaskan oleh Haripin dapat menimbulkan dua krisis kembar yaitu pertama, perpanjangan masa pembatasan sosial berskala besar (PSBB) di berbagai provinsi akan menekan daya tahan kelompok masyarakat ke titik ekstrem/membahayakan sehingga membuka peluang keamanan bagi kemunculan "krisis keamanan" dan yang kedua mengikuti krisis yang pertama munculnya krisis keamanan yang tidak tertangani secara komprehensif dan berkeadilan dapat berubah menjadi sebuah krisis politik seperti sejarah Indonesia dahulu (Haripin 2020). Dan yang terakhir dampak pada pendidikan oleh Purwanto et al yang menuliskan terdapat kendala yang dialami oleh murid, guru dan orang tua dalam kegiatan belajar mengajar online yaitu dari faktor penguasaan teknologi yang masih kurang, peningkatan biaya hidup dari pemakaian internet, dan adanya pekerjaan tambahan bagi orang tua yang harus mendampingi anak belajar, komunikasi dan sosialisasi antara murid, guru, dan orang tua menjadi berkurang dan jam kerja yang menjadi tidak terbatas bagi guru karena harus berkomunikasi dan berkoordinasi dengan orang tua, guru lain, dan kepala sekolah (Purwanto et al. 2020). Kesimpulan dari kategori yang kedua yaitu dampak yang ditimbulkan oleh pandemi Covid-19, kajian-kajian literatur terdahulu lebih banyak membahas tentang dampak dari Covid-19 terhadap ekonomi dunia pada level sistem internasional. Sedangkan pada level negara baik itu negara maju ataupun negara berkembang dampak yang signifikan terlihat pada keamanan dan ekonomi dari negara tersebut. Dalam level yang lebih rendah lagi dapat dilihat aspek masyarakat dari negara berkembang yang memiliki ancaman krisis yang sangat serius dan dari sektor pendidikan. Kekurangan dari kategori ini adalah tidak adanya solusi yang diberikan penulis sebelumnya yang dapat mengeluarkan negara dari keadaan tersebut berbeda dari yang ditulis oleh penulis-penulis pada kategori pertama yang memberikan solusi dan saran untuk memutus rantai penyebaran Covid-19. Dari kedua kategori yang digunakan pada penelitian ini dapat ditarik kesimpulan pembaruan yang ditawarkan penulis pada topik yang berhubungan dengan Covid-19 adalah penggunaan sekuritisasi yang dilakukan oleh suatu negara terhadap ancaman yang datang dari pandemi Covid-19 yang bersifat non-tradisional dan implikasi dari sekuritisasi yang diberlakukan suatu negara terhadap hubungan luar negeri negara tersebut dalam hal ini objek penetian penulis adalah Indonesia.

\subsection{Kerangka Pemikiran}

Studi hubungan internasional mengalami evolusi dalam perjalanannya khususnya pada bidang keamanan. Pergeseran perpektif keamanan berubah dengan cepat pasca tragedi 9/11 atau runtuhnya gedung world trade center (WTC) pada 9 November 2011 oleh serangan teroris. Studi keamanan mengalami penambahan ancaman yang hadir terhadap negara tidak lagi hanya ancaman tradisional atau militer akan tetapi ancaman juga datang dari sisi nontradisional (bukan militer). Copenhagen school menghadirkan pembahruan cara pandang 
terhadap studi keamanan pasca perang dingin. Copenhagen school berargumen bahwa diperlukannya adanya deepening (pendalaman) dan widening (perluasan) dalam studi keamanan. Pendalaman yang dimaksud adalah dari level aktor yang terlibat tidak hanya terfokus kepada negara, akan tetapi level aktor bisa meluas dari sistem internasional hingga individu. Sedangkan perluasan adalah ancaman yang datang kepada aktor atau objek yang terlibat tidak hanya dari militer namun ancaman bisa datang dari bidang yang lain di dalam kehidupan baik itu kesehatan, ekonomi, teknologi dan lain-lain. Copenhagen school selanjutnya beranggapan lebih menarik untuk melihat proses terciptanya dinamika keamanan yang dapat membingkai suatu isu menjadi isu keamanan dalam kondisi tertentu (Buzan, Weaver, and Wilde 1998).

Buzan, Weaver dan Wilde menawarkan konsep sekuritisasi yang melihat keamanan sebagai sebuah proses pembingkaian sebuah isu berawal dari aktor sekuritisasi melihat sebuah masalah yang dinilai dapat mengancam objek yang dilindungi, kemudian aktor sekuritisasi meyakinkan objek yang dilindungi dalam hal ini objek berubah menjadi audiens, setelah itu langkah-langkah luar biasa yang dianggap oleh aktor sekuritisasi mampu mengatasi ancaman yang dihadapi oleh objek mendapatkan kekuatan legitimasi untuk mengatasi ancaman yang datang (Buzan, Weaver, and Wilde 1998, 34). Kemudian Kurniawan berdasar dari Buzan et al menjelaskan secara lebih jelas yang dimaksud oleh Buzan et al mengenai bagaimana sekuritisasi bisa berjalan. Yang pertama adanya existential threat (ancaman), yang kedua adanya refrent object (objek yang dilindungi), yang ketiga emergency situation (keadaan darurat, dan yang terakhir extraordinary measure. Keempat variabel tersebut memiliki peran yang saling berkait antara satu dan yang lain. Menurut kuriawan komponen sekekuritisasi dapat dibagi menjadi empat yaitu aktor sekuritisasi, Speech Act, existential threat, referent object (audiens). Dari variabel-variabel diatas penulis menggabungkan variabel yang nantinya akan dipakai pada penelitian ini menjadi aktor sekuritisasi, Speech Act, existential threat, referent object dan extra ordinary measure (tindakan luar biasa) sebagai varibel penelitian kali ini.

\section{Metode Peneltitian}

Penelitian ini mengunakan metodologi kualitatif, di mana menurut Alan Bryman, penelitian kualitatif merupakan strategi penelitian yang lebih mementingkan pernyataanpernyataan daripada angka-angka atau non-numerik (Bryman 2012). Terdapat tiga jenis penelitian kualitatif yang pertama deduktif, yang kedua konstruktif, dan yang ketiga interpretatif. Pada penelitian ini penulis menggunakan penelitian deduktif.

Penelitian deduktif digunakan penulis untuk menjelaskan suatu fenomena berdasarkan kerangka analisis sebelumnya. Penggunaan teknik penelitian deduktif pada penelitian ini dengan cara menyusun kerangka analisis dan mengaplikasikannya dengan data-data yang dimiliki penulis. Kemudian data-data yang dimiliki penulis diaplikasikan kepada konsep sekuritisasi yang sudah dijelaskan sebelumnya yang diharapkan dapat menjadi sumber informasi baru untuk peneliatan-penelitian berikutnya.

\section{Hasil dan Pembahasan}

\subsection{Aktor sekuritisasi}

Aktor sekuritisasi merupakan aktor yang berdaulat yang dapat mengambil keputusan yang dinilai rasional dalam situasi yang sedang dihadapi. Lazimnya aktor sekuritisasi memiliki kekuatan untuk meyakinkan audiens akan ancaman yang datang (Peoples and 
Vaughan-Williams 2010). Aktor sekuritisasi memiliki fungsi yang sangat penting dalam proses sekuritisasi tidak hanya sebagai orator untuk meyakinkan audiens tentang ancaman namun aktor sekuritisasi harus juga meredakan situasi yang sedang terjadi pada masyarakat. Pada kasus Covid-19 yang dianggap penulis merupakan aktor sekuritisasi adalah Presiden Republik Indonesia Joko Widodo, menteri kesehatan Letjen TNI (Purn) Dr. dr. Terawan Agus Putranto, Sp. Rad. (K), gubenur DKI Jakarta Anies Baswedan, dan kepala-kepala daerah lainnya di Indonesia.

Walaupun pada prakteknya aktor sekuritisasi di Indonesia melakukan desekuritisasi terhadap ancaman pandemi covid-19 sebelum melakukan praktek sekuritisasi yang membuat terhambatnya proses sekuritisasi itu sendiri (Chairil 2020). Namun pada akhirnya Pemerintah Indonesia melakukan langkah-langkah taktis dalam menghadapi pendemi covid-19 (Zahrotunnimah 2020). Dalam proses sekuritisasi covid-19 di Indonesia terdapat hal unik dan menarik yang dapat dilihat, bahwa sebelum adanya himbauan langsung yang terpusat dari pemeritah pusat beberapa kepala daerah sudah melakukan langkah-langkah taktis terkait pandemi covid-19 seperti pemerintah provinsi DKI Jakarta meniadakan car free day pada 11 Maret 2020 kemudian menghimbau kepada jajaran Pemprov yang memiliki gejala Covid-19 untuk melapor dan menunda penyelenggaraan Formula E yang akan dilaksanakan pada bulan Juni, Pemerintah Jawa Timur mengambil langkah taktis yang dibagi ke dalam 6 bidang yaitu perhubungan, pendidikan, kesehatan, pemerintahan, ekonomi, dan informasi, terakhir Pemerintah Provinsi Jawa Barat merumahkan siswa dan menghentikan kegiatan massal serta membangun pusat informasi dan koordinasi Covid-19 di Jawa Barat yang bisa diakses seluruh lapisan masyarakat, Pemerintah Provinsi Jawa Timur, Pemerintah Kota Surabaya (Zahrotunnimah 2020). Terlihat dalam hal ini aktor sekuritisasi yang mampu berperan dalam berjalannya proses sekuritisasi di Indonesia tidak hanya terpusat pada pemerintah pusat Indonesia. Pemerintah-pemerintah daerah mampu berfikir rasional akan ancaman yang dihadapi oleh Indonesia di daerah masing-masing. Presiden Republik Indonesia Jowo Widodo kemudian memberikan perintah untuk memberlakukan pembatasan sosial berskala besar atau PSBB (Pribadi 2020).

\subsection{Speech Act}

Speech Act merupakan proses dimana aktor sekuritisasi melakukan orasi atau mengeluarkan kebijakan yang pada dasarnya dilakukan untuk meyakinkan audiens akan adanya ancaman yang datang kepada objek yang dilindungi. Speech Act merupakan variabel paling penting selanjutnya dari sekuritisasi karena Speech Act dinilai landasan dari keberhasilan atau gagalnya proses sekuritisasi yang dilakukan oleh aktor sekuritisasi. Emmers mendefinisikan Speech Act sebagai ujaran atau tindakan yang bertujuan untuk memengaruhi audiens atau masyarakat untuk melihat suatu isu atau situasi. Ujaran yang dimaksud berguna untuk mengkonstruksi ancaman yang datang menjadi sebuah legitimasi yang dapat mendasari tindakan selanjutnya yang akan diambil oleh negara untuk melakukan tindakan luar biasa untuk menghilangkan ancaman (Emmers 2016). Proses Speech Act yang terjadi di Indonesia tidak seperti yang biasanya. Proses Speech Act yang dilakukan oleh Indonesia dimulai dengan melakukan desekuritisasi. Desekuritisasi adalah suatu proses di mana aktor-aktor menjauhkan isu-isu tertentu dari ranah keamanan dan kembali memasuki ranah politik normal. Begitu suatu isu didesekuritisasi, isu tersebut tidak akan ditangani dengan logika keamanan dan tidak dinyatakan sebagai ancaman, tetapi dikembalikan ke ruang publik biasa (Chairil 2020). Proses desekuritisasi bisa dilihat pada tabel dibawah 
Tabel 1 Pernyataan Desekuritisasi Pemerintah

\begin{tabular}{|c|c|c|}
\hline Tanggal & Pejabat Pemerintah & pernyataan \\
\hline 27 Januari 2020 & $\begin{array}{l}\text { Menteri Kesehatan Terawan Agus } \\
\text { Putranto }\end{array}$ & $\begin{array}{l}\text { Pencegahan virus korona } \\
\text { adalah dengan tidak panik dan } \\
\text { resah, "enjoy" saja, dan makan } \\
\text { secukupnya (Redaksi WE } \\
\text { Online 2020) }\end{array}$ \\
\hline 7 Februari 2020 & Menko Polhukam Mahfud MD & $\begin{array}{l}\text { Indonesia adalah satu-satunya } \\
\text { negara besar di Asia yang } \\
\text { belum memiliki kasus positif } \\
\text { virus korona (CNN Indonesia } \\
\text { 2020a) }\end{array}$ \\
\hline 11 Februari 2020 & Menkes Terawan Agus Putranto & $\begin{array}{l}\text { Mendiskreditkan penelitian } \\
\text { Harvard T.H. Chan School of } \\
\text { Public Health (Ezalia et al. } \\
\text { 2020), yang menyimpulkan } \\
\text { bahwa virus Korona } \\
\text { seharusnya sudah ada di } \\
\text { Indonesia, tetapi tidak } \\
\text { terdeteksi (CNN Indonesia } \\
\text { 2020b) }\end{array}$ \\
\hline 15 Februari 2020 & $\begin{array}{l}\text { Menko Perekonomian Airlangga } \\
\text { Hartarto, dikutip oleh Menko } \\
\text { polhukam Mahfud MD }\end{array}$ & $\begin{array}{l}\text { Virus Korona tidak dapat } \\
\text { masuk Indonesia karena } \\
\text { perizinan berbelit-belit } \\
\text { (Mahfud MD 2020) }\end{array}$ \\
\hline 17 Februari 2020 & Menhub Budi Karya Sumadi & $\begin{array}{l}\text { Bercanda bahwa tidak ada } \\
\text { virus korona di Indonesia } \\
\text { karena masyarakat kebal } \\
\text { karena suka makan nasi } \\
\text { kucing. (Saubani 2020) }\end{array}$ \\
\hline 24 Februari 2020 & $\begin{array}{l}\text { Sekretaris Ditjen P2P Kemenkes } \\
\text { Achamd Yurianto }\end{array}$ & $\begin{array}{l}\text { Warga Jepang yang dites } \\
\text { positif terinfeksi virus SARS- } \\
\text { CoV-2 setelah kembali dari } \\
\text { perjalanan ke Indonesia } \\
\text { bukanlah kasus COVID-19. Ia } \\
\text { bersikeras bahwa SARS-CoV- } \\
2 \text { berbeda dari COVID-19, } \\
\text { padahal COVID-19 adalah } \\
\text { nama penyakitnya, sementara } \\
\text { virus yang menyebabkannya } \\
\text { dinamai SARS-CoV-2 oleh } \\
\text { Komite Internasional } \\
\text { Taksonomi Virus (ICTV). } \\
\text { (Aqil 2020) }\end{array}$ \\
\hline 26 Februari 2020 & Wakil Presiden Ma'ruf Amin & $\begin{array}{l}\text { Virus korona tidak berani } \\
\text { datang ke Indonesia karena doa } \\
\text { kunut ulama dan istigasah. }\end{array}$ \\
\hline
\end{tabular}


Jurnal Asia Pacific Studies

Volume 4 Number 1/ January - June 2020

\begin{tabular}{|l|l|l|}
\hline & & (Maranda 2020) \\
\hline 29 Februari 2020 & $\begin{array}{l}\text { Staf Ahli Utama KSP Ali Mochtar } \\
\text { Ngabalin }\end{array}$ & $\begin{array}{l}\text { Tidak ada virus Korona di } \\
\text { Indonesia karena virus tersebut } \\
\text { tidak berkembang kuat di } \\
\text { negara tropis.(Tribun News } \\
\text { 2020) }\end{array}$ \\
\hline
\end{tabular}

Sumber: diolah kembali dari Chairil 2020

Dampak dari Speech Act desekuritisasi sendiri adalah menurunkan ketegangan atau situasi yang ada pada masyakarat agar tidak muncul kepanikan dalam masyarakat. Banyak pandangan yang berbeda pada peneliti lain. Tangguh melihat Speech Act yang dilakukan oleh aktor sekuritisasi Indonesia menunjukkan bahwa pemerintah Indonesia tidak memiliki rasa krisis maupun kapasitas untuk merespon krisis, sehingga cenderung meremehkan penyakit ini (Chairil 2020). Speech Act yang dilakukan diawal menurut Chairil sebagai penghambat sekuritisasi yang bisa dilakukan oleh pemerintah Indonesia (Chairil 2020). Speech Act sekuritisasi di Indonesia dimulai dengan wacana Presiden Republik Indonesia pada 30 Maret 2020 yang berbunyi "Saya minta kebijakan pembatasan sosial berskala besar, physical distancing dilakukan lebih tegas, lebih disiplin, dan lebih efektif lagi. Sehingga tadi sudah saya sampaikan bahwa perlu didampingi adanya kebijakan darurat sipil" (Firdausi 2020). Kemudian penyataan Joko Widodo mengenai perkiraan dimasa depan yang "Semua skenario kita siapkan dari yang ringan, moderat, sedang, sampai kemungkinan yang terburuk. Darurat sipil itu kita siapkan apabila terjadi kondisi abnormal. Perangkatnya kita siapkan. (Kompas.com 2020b). Hal yang serupa juga dilakukan oleh Ridwan Kamil selaku Gubernur Jawa Barat yang menyatakan status keadaan tertentu darurat becana wabah penyakit akibat Covid-19 sebagaimana dimaksud berlaku sampai dengan tanggal 29 Mei 2020 dan dapat diperpanjang ataupun diperpendek sesuai kebutuhan penyelenggaraan penanganan darurat bencana di lapangan (Sutrisno 2020). Speech Act yang dilakukan pemerintah Indonesia baik dari pusat dan daerah dinilai penulis sudah menggambarkan cara pemerintah untuk meyakinkan masyarakat dengan keadaaan darurat yang dihadapi oleh Bangsa Indonesia pada saat ini. Speech Act yang dilakukan berusaha membingkai isu pandemi Covid-19 menjadi isu yang mengancam keamanan negara Indonesia.

\subsection{Existential Threat (Ancaman)}

Variabel selanjutnya dari Sekuritisasi adalah Existential Threat definisi ancaman yang muncul kepada suatu objek keamanan atau menurut Williams adalah situasi dimana terdapat kerentanan dengan level tertinggi (Williams 2003). Dalam kasus sekuritisasi kali ini tentu saja existential threat yang dihadapi oleh Indonesia dan dunia pada saat ini adalah pandemi SARS-CoV-2 atau yang lebih dikenal dengan sebutan Covid-19. Covid-19 pertama kali terdeteksi di Indonesia pada 2 Maret 2020, tepatnya di Depok (Kompas.com 2020a). Sejak terdeteksinya Covid-19 pada 2 orang yang berdomisili di Depok pertumbuhan Covid-19 terus meningkat. Covid-19 seperti yang telah dijelaskan pada variabel sebelumnya berubah menjadi bencana nasional yang skenarionya telah diprediksi oleh pemerintah baik dari level terendah hingga tertinggi. Bisa dilihat dari grafik yang dapat dilihat dibawah. 


\section{Grafik 1. Peningkatakan Kasus Covid-19}

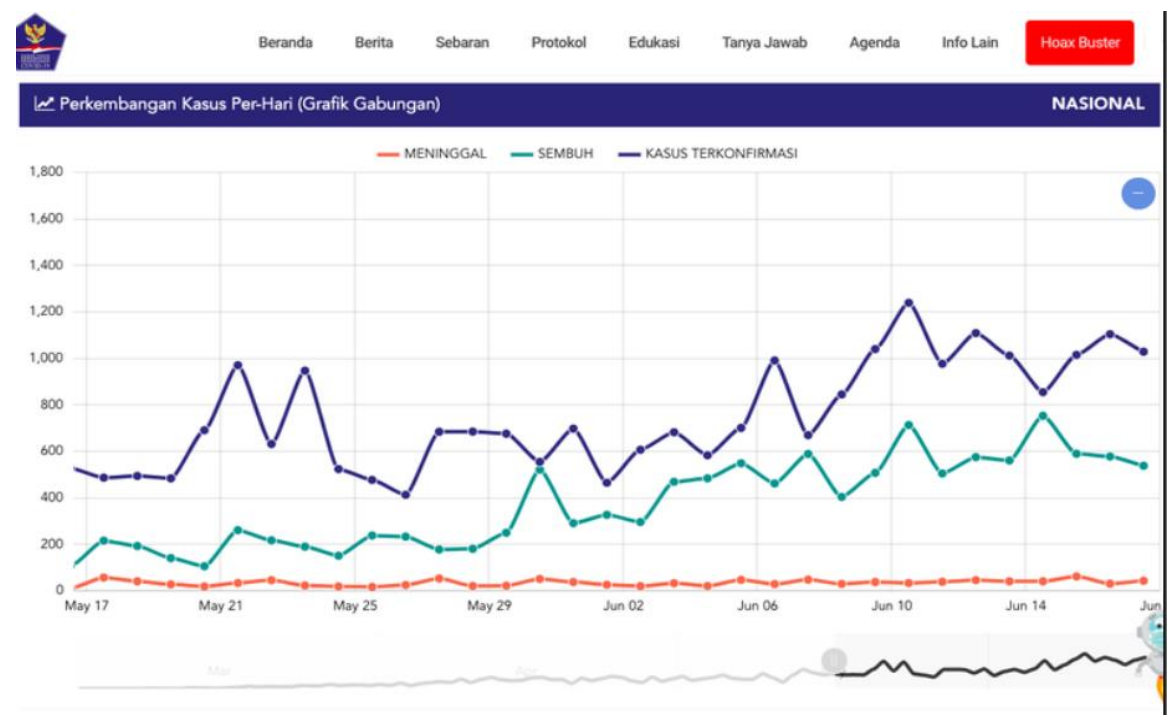

Sumber : (kompas.com 2020)

Pertanggal 14 Juni 2020 pemerintah Indonesia melalui juru bicara pemerintah untuk penanganan virus Covid-19 menyebutkan total ada 36.277 kasus di Tanah Air (Prabowo, Hakim, and Farisa 2020). Semakin tingginya tingkat pertambahan dari sebaran virus Covid19 menurut ahli epidemologi Universitas Indonesia Pandu Riono penyebab naik turunnya grafik dari Covid19 yang kemungkinan besar merupakan dampak dari hari raya Idul Fitri 1441 lalu (Tribunnews Mataram 2020). Dapat dilihat dari grafik dan angka yang sudah dipaparkan oleh penulis adanya ancaman yang mengancam keberlangsungan hidup dari masyarakat Indonesia menjadi alasan bahwa ancaman tersebut benar adanya. Disamping itu ada juga dampak yang diprediksi menjadi masalah baru bagi pemerintah Indonesia yaitu ketakutan akan adanya krisis yang dapat terjadi baik itu dari politik keamanan ataupun krisis ekonomi(Haripin 2020).

\subsection{Referent Object (Audiens)}

Referent Object secara singkat dapat dijelaskan adalah pihak yang diyakinkan oleh speech act yang dilakukan oleh aktor sekuritisasi dan yang diancam keberlangsungan hidupnya dari ancaman yang datang. Rita Floyd dalam tulisannya menjelaskan bahwa pada dasarnya audience tidak memiliki andil besar pada proses sekuritisasi dan bahkan bukan bagian dari konsep analitis melainkan lebih kepada sesuatu yang sifatnya normatif (Floyd 2011). Berdasarkan apa yang dituliskan Floyd sebenarnya audience tidak memiliki peranan yang signifikan hal ini bisa dijelaskan oleh Hansen dalam tulisannya dengan jargon technification dimana dalam situasi tertentu audience dipaksa untuk melakukan apa yang diperintahkan oleh pemerintah, hal tersebut diharapkan dapat menjadi solusi dari masalah yang dihadapi oleh sekuritisasi aktor (Lacy and Prince 2018). Referent object dalam penelitian kali ini tidak lain adalah masyarakat Indonesia. Seperti tercantum dalam pembukaan UUD 1945 bahwa "pemerintah negara Indonesia berkewajiban untuk melindungi segenap bangsa Indonesia dan seluruh tumpah darah Indonesia ....". dalam hal ini objek yang harus dilindungi oleh pemerintah Indonesia adalah keseluruhan dari bangsa Indonesia baik itu dari masyarakat, aspek keamanan, politik, ekonomi dan lain-lain. 
Sekuritisasi yang dilakukan Pemerintah Indonesia terhadap segala aspek baik itu aspek sosial, ekonomi, keamanan, dan lain-lain menempatkan masyarakat Indonesia pada level tertinggi dari dalam apa yang dilindungi oleh pemerintah. Kebijakan yang diberlakukan mempengaruhi kondisi sosial dan ekonomi dari masyakakat. Diberlakukannya PSBB dengan tujuan memutus rantai penyebaran Covid-19 membuat kemampuan ekonomi sebagian besar masyarakat Indonesia. Menkeu Republik Indonesia menyebutkan dalam laman voaindonesia bahwa pertumbuhan ekonomi Indonesia dapat mengalami penuruan hingga minus 0,4 persen (Intan 2020). Bantuan yang diberikan pemerintah Indonesia demi meringankan beban yang dihadapi oleh masyarakat dapat dilihat dari 7 jenis bantuan yang sudah diberikan oleh pemerintah yaitu bantuan sembako, bantuan sosial tunai, BLT dana desa, listrik gratis, kartu prakerja, subsidi gaji karyawan, BLT usaha mikro kecil (ihsanuddin 2020).

\subsection{Extraordinary Measure (Tindakan Luar Biasa)}

Extraordinary Measure atau tindakan luar biasa dapat didefinisikan, suatu tindakan yang diberlakukan oleh aktor sekuritisasi yang bertujuan untuk mengeliminir ancaman yang datang. Dengan menggunakan Speech Act sebagai alat untuk melegitimasi tindakan yang akan diambil dengan membingkai suatu isu sebagai ancaman dalam situasi darurat. Negara akan mengerahkan segala daya dan upaya untuk mengeliminir ancaman yang datang sekalipun itu melibatkan kekuatan negara tersebut (Buzan, Weaver, and Wilde 1998). Tindakan luar biasa yang dilakukan oleh pemerintah Indonesia dalam menghadapi Covid-19 antara lain pada tanggal 27 Januari 2020, kementrian kesehatan mengumumkan telah memasang 195 pemindai termal yang tersebar di 135 pintu masuk nasional serta menyiapkan 100 rumah sakit untuk menangani pasien yang diidenfikasi atau terinfeksi virus Covid-19 (Gunadha and Aditya 2020). Melalui laman Kementrian Luar negeri Indonesia, Pemerintah Indonesia melalui Mentri kesehatan telah mengembangkan pedoman kesiap siagaan mengacu pada pedoman sementara yang disusun oleh WHO, menyusun panduan bagaimana mengurangi risiko terjangkit Covid-19, kemudian kementrian kesehatan membuka kontak layanan yang dapat diakses oleh masyakarat untuk mencari informasi perihal virus Covid-19 (Kementrian Luar Negeri Indonesia 2020).

Tepatnya pada tanggal 2 Februari 2020 pemerintah Indonesia mengumkan penundaan seluruh penerbangan dari dan ke Tiongkok yang berlaku mulai tanggal 5 Februari 2020, melarang semua orang masuk dan transit ke Indonesia apabila selama 14 hari terakhir berada di Tiongkok, serta mencabut sementara bebas visa dan visa on arrival untuk warga negara Tiongkok. Kementrian perdangangan pada 4 Februari 2020 menghentikan impor hewan hidup dari Tiongkok (Kementrian Luar Negeri Indonesia 2020). Kemudian sebagai bentuk nyata dari pembukaan UUD 1945 pemerintah Indonesia mengevakuasi warga negara Indonesia dari Provinsi Hubei, Tiongkok pada tanggal 2 Februari 2020 serta memberika bantuan logistik sebesar 133 juta bagi WNI yang berada di kota Wuhan dan melalui kementrian luar negeri BNPB mengirimkan 10.000 masker n-95 pada untuk WNI di Tiongkok (Kementrian Luar Negeri Indonesia 2020). Pemerintah melakukan evakuasi pada 188 orang WNI dari kapal World Dream dan 69 orang WNI dari kapal Diamond Princess dan kemudian dikarantina di pulau Sebaru kecil, Jakarta selama 14 hari (Laosana 2020). Dari dalam negeri Presiden Republik Indonesia Joko Widodon menandatangani KEPPRES menetapkan Covid-19 sebagai bencana nasional (Ihsanuddin 2020). Menurunkan intel dan polri serta memberlakukan PSBB guna melakukan pelacakan, menertibkan masyarakat dan diharapkan dapat memutus rantai penyebaran Covid-19 (Pribadi 2020; CNN 2020). 


\subsection{Implikasi Sekuritisasi Hubungan Luar Negeri Indonesia}

Dalam sektor ekonomi, pemberhentian impor dan dicabutnya visa dan visa on arrival oleh pemerintah Indonesia terhadap barang-barang asal Tiongkok dan wisatawan asal Tiongkok tampaknya mempengaruhi hubungan antar kedua negara. Duta besar Tiongkok untuk Indonesia Xiao Qian menuturkan kebijakan yang diambil indonesia dapat merugikan Indonesia sendiri baik dari sektor pariwisata dan juga perdagangan (Chaterine 2020). Xiao Qian juga menggelar jumpa pers terkait kebijakan tersebut yang akan berdampak kepada hubungan Indonesia-Tiongkok (JPNN 2020). Sekuritisasi Covid-19 juga berpengaruh kepada kebijakan pemerintah yang lain seperti pelaksanaan ibadah haji 2020 bisa saja ditangguhkan (Rohman 2020). Kemudian ketidak siapan Indonesia dalam menghadapi pandemi Covid-19 membuat pemerintah Australia menarik duta besar Australia untuk Indonesia Gary Quinlan pulang ke Negeri Kangguru (RMCO 2020).

Pada Sektor Kesehatan Extraordinary Measure dari pemerintah Indonesia juga dapat dilihat pada kerja sama dalam sektor kesehatan yang dilakukan oleh pemerintah Indonesia dengan berbagai negara seperti Jepang, Amerika Serikat, Singapura, Tiongkok, Vietnam, Korea Selatan, Australia, dan Uni Emirat Arab (tirto 2020). Hubungan kerja sama yang dilakukan dengan negara-negara tersebut merupakan kerja sama dalam pengadaaan alat kesehatan serta obat-obatan yang diperlukan dalam menghadapi Covid-19 (tirto 2020).

\section{Kesimpulan}

Berdasarkan pembahasan diatas sekuritisasi yang diberlakukan oleh pemerintah Indonesia sudah memiliki arah dan pedoman yang cukup baik akan tetapi eksekusi dilapangan yang belum maksimal, membuat adanya kesalahan prediksi pada data yang diperoleh pemerintah. Cara pembingkaian suatu isu menjadi ancaman dilakukan dengan melibatan intel dan polri dalam mengantisipasi juga dinilai penulis sudah tepat. Perlunya kesadaran dari masyarakat dan diplomasi publik yang harus dilakukan pemerintah dengan lebih baik lagi. Pepatah yang mengatakan lebih baik terlambat daripada tidak merupakan pepatah yang sangat tepat untuk mengambarkan situasi yang terjadi pada saat ini. Masyarakat harus dapat memposisikan diri sebagai salah satu pejuang dalam menghadapi Covid-19 tidak hanya memposisikan diri sebagai korban dari kebjikan yang diberlakukan oleh pemerintah, kedisiplinan dalam menerapakan protokol yang diberlakukan oleh pemerintah dapat menjadi salah satu cara masyarakat memperlihatakn koordinasi masyakarat dalam memerangi Covid19. Rekomendasi pada penelitian selanjutnya dapat berfokus bagaimana kerja sama Indonesia dengan negara-negara yang dianggap berhasil mengatasi pertumbuhan virus Covid-19 dengan

cepat. Kemudian penelitian selanjutnya juga bisa membanding proses sekuritisasi pandemi SARS pada 2003 dan flu burung pada 2005 di Indonesia- 


\section{DAFTAR PUSKATA}

\section{Buku}

Bryman, Alan. 2012. Social Research Method. 4th Edition. Oxford University press.

Buzan, Barry, Ole Weaver, and Jaap de Wilde. 1998. Security: A New Framework For Analysis. London: Lynne Rienner.

Emmers, Raft. 2016. Securitization In Contemporary Security Studies.

\section{Jurnal}

Burhanuddin, Chairul Iksan, and Muhammad Nur Abdi. 2020. "KRISIS EKONOMI GLOBAL DARI DAMPAK PENYEBARAN VIRUS CORONA (COVID-19)"17: 710-18.

Ezalia, E, Irmi Elfina R, G Elizabeth, W A N Hayati My, A Norhanim, A Wahidah, Chin Ym, et al. 2020. "Using Predicted Imports of 2019-NCoV Cases to Determine Locations That May Not Be Identifying All Imported Cases." Orphanet Journal of Rare Diseases 21 (1): 1-9. https://doi.org/10.1155/2010/706872.

Floyd, Rita. 2011. "Can Securitization Theory Be Used in Normative Analysis? Towards a Just Securitization Theory." Security Dialogue 42 (4-5): 427-39. https://doi.org/10.1177/0967010611418712.

Gronvall, Gigi Kwik. 2020. "The Scientific Response to COVID-19 and Lessons for Security." Survival 62 (3): 77-92. https://doi.org/10.1080/00396338.2020.1763613.

Hanoatubun, Silpa. 2020. "Dampak Covid - 19 Terhadap Perekonomian Indonesia." EduPsyCouns Journal 2 (2): 146-53.

Indriya. 2020. "Kosep Tafakur Dalam Al-Quran Dalam Menyikapi Corona Cirus." Jurnal Sosial Budaya 7 (3): 211-16. https://doi.org/10.1017/CBO9781107415324.004.

Kitchin, Rob. 2020. "Civil Liberties or Public Health, or Civil Liberties and Public Health? Using Surveillance Technologies to Tackle the Spread of COVID-19." Space and Polity 0 (0): 1-20. https://doi.org/10.1080/13562576.2020.1770587.

Lacy, Mark, and Daniel Prince. 2018. "Securitization and the Global Politics of Cybersecurity." Global Discourse 8 (1): 100-115. https://doi.org/10.1080/23269995.2017.1415082.

Lisbet. 2020. "Penyebaran Covid-19 Dan Respons Internasional.” Info Singkat XII (5): 7-12.

Mukharom, Mukharom, and Havis Aravik. 2020. "Kebijakan Nabi Muhammad Saw Menangani Wabah Penyakit Menular Dan Implementasinya Dalam Konteks Penanggulangan Coronavirus Covid-19." SALAM: Jurnal Sosial Dan Budaya Syar-I 7 (3). https://doi.org/10.15408/sjsbs.v7i3.15096.

Ozili, Peterson K, and Thankom Arun. 2020. "Spillover of COVID-19: Impact on the Global Economy." SSRN Electronic Journal, no. March. https://doi.org/10.2139/ssrn.3562570.

Peoples, Columba, and Nick Vaughan-Williams. 2010. Critical Security Studies: An Introduction. Critical Security Studies: An Introduction. Vol. 9780203847. https://doi.org/10.4324/9780203847473.

Syawfi, Idil. 2020. "Implikasi Pandemi COVID-19 Terhadap Hubungan Internasional: Menuju Dunia Paska-Liberal." Jurnal Ilmiah Hubungan Internasional -Pacis 2019 (April).

http://103.36.68.33/index.php/JurnalIlmiahHubunganInternasiona/article/view/3864/2 
909.

Telaumbanua, Dalinama. 2020. "Urgensi Pembentukan Aturan Terkait Pencegahan Covid-19 Di Indonesia." QALAMUNA: Jurnal Pendidikan, Sosial, Dan Agama 12 (01): 59-70. https://doi.org/10.37680/qalamuna.v12i01.290.

Williams, Micheal C. 2003. "Words , Images , Enemies: Securitization and International Politics.” Nternational Studies Quarterly 47 (4): 511-31.

Yunus, Nur Rohim, and Annissa Rezki. 2020. "Kebijakan Pemberlakuan Lock Down Sebagai Antisipasi Penyebaran Corona Virus Covid-19." SALAM: Jurnal Sosial Dan Budaya Syar-I 7 (3). https://doi.org/10.15408/sjsbs.v7i3.15083.

Zahrotunnimah, Zahrotunnimah. 2020. "Langkah Taktis Pemerintah Daerah Dalam Pencegahan Penyebaran Virus Corona Covid-19 Di Indonesia." SALAM: Jurnal Sosial Dan Budaya Syar-I 7 (3). https://doi.org/10.15408/sjsbs.v7i3.15103.

\section{Website}

Aqil, Muhumamad Ibnu. 2020. “'It Is Not COVID-19': Indonesian Health Official Mixes up Disease and Virus - National - The Jakarta Post." February 25, 2020. https://www.thejakartapost.com/news/2020/02/25/it-is-not-covid-19-health-officialmixes-up-disease-and-virus.html.

Asamara, Chandra Gian. 2020. "Jokowi Sebut Tak Ada Satupun Negara Yang Siap Hadapi Covid-19.” April 30, 2020. https://www.cnbcindonesia.com/news/20200430133235-4155529/jokowi-sebut-tak-ada-satupun-negara-yang-siap-hadapi-covid-19.

Baskara, Bima. 2020. "Rangkaian Peristiwa Pertama Covid-19." April 18, 2020. https://bebas.kompas.id/baca/riset/2020/04/18/rangkaian-peristiwa-pertama-covid-19/.

BBC. 2012. "Indonesia Negara Dengan Kasus Flu Burung Terbanyak Di Dunia - BBC News Indonesia." March 8, 2012. https://www.bbc.com/indonesia/berita_indonesia/2012/03/120308_birdfluindonesia.

Chairil, Tangguh. 2020. "Respons Pemerintah Indonesia Terhadap Pandemi COVID-19: Desekuritisasi Di Awal, Sekuritisasi Yang Terhambat - International Relations BINUS University." March 23, 2020. https://ir.binus.ac.id/2020/03/23/responspemerintah-indonesia-terhadap-pandemi-covid-19-desekuritisasi-di-awal-sekuritisasiyang-terhambat/\#_edn72.

Chaterine, Rahel Narda. 2020. "Dubes China Sayangkan RI Setop Penerbangan Dan Impor Pangan.” February 4, 2020. https://finance.detik.com/berita-ekonomi-bisnis/d4885649/dubes-china-sayangkan-ri-setop-penerbangan-dan-impor-pangan.

CNN. 2020. "Libatkan Intelijen, Jokowi Tangani Corona Tanpa Suara." March 13, 2020. https://www.cnnindonesia.com/nasional/20200313144756-20-483177/libatkanintelijen-jokowi-tangani-corona-tanpa-suara.

CNN Indonesia. 2020a. "Mahfud: RI Satu-Satunya Negara Besar Di Asia Tak Kena Corona." February 7, 2020. https://www.cnnindonesia.com/nasional/20200207194915-20472750/mahfud-ri-satu-satunya-negara-besar-di-asia-tak-kena-corona.

. 2020b. "Menkes Tantang Harvard Buktikan Virus Corona Di Indonesia." February 11, 2020. https://www.cnnindonesia.com/nasional/20200211195637-20473740/menkes-tantang-harvard-buktikan-virus-corona-di-indonesia.

Ernes, Yogi. 2020. "TNI Sebut Corona Ancaman Keamanan Nasional, Minta Pemerintah Buat Aturan." April 28, 2020. https://news.detik.com/berita/d-4995020/tni-sebutcorona-ancaman-keamanan-nasional-minta-pemerintah-buat-aturan.

Firdausi, Fadrik. 2020. "Darurat Sipil Covid-19 \& Sejarah Status Keadaan Bahaya Di Indonesia - Tirto.ID.” April 7, 2020. https://tirto.id/darurat-sipil-covid-19-sejarah- 
status-keadaan-bahaya-di-indonesia-eKUE.

Gunadha, Reza, and Rifan Aditya. 2020. "5 Cara Indonesia Selamatkan Warganya Dari Ancaman Virus Corona." 2020. https://www.suara.com/news/2020/02/01/163313/5-cara-indonesia-selamatkanwarganya-dari-ancaman-virus-corona.

Haripin, Muhamad. 2020. "Dampak Politik-Keamanan COVID-19.” April 29, 2020. http://www.politik.lipi.go.id/kolom/kolom-2/politik-nasional/1383-dampak-politikkeamanan-covid-19.

ihsanuddin. 2020. "Ada 7 Bantuan Pemerintah Selama Pandemi Covid-19, Berikut Rinciannya... Halaman All - Kompas.Com.” August 26, 2020. https://nasional.kompas.com/read/2020/08/26/09222471/ada-7-bantuan-pemerintahselama-pandemi-covid-19-berikut-rinciannya?page=all.

Ihsanuddin. 2020. "Presiden Jokowi Teken Keppres Tetapkan Wabah Covid-19 Bencana Nasional." April 13, 2020. https://nasional.kompas.com/read/2020/04/13/18101841/presiden-jokowi-tekenkeppres-tetapkan-wabah-covid-19-bencana-nasional.

Intan, Ghita. 2020. "Menkeu: Dampak Covid-19, Pertumbuhan Ekonomi Indonesia 2020 Bisa Minus 0,4 Persen." April 2, 2020. https://www.voaindonesia.com/a/menkeu-dampakcovid-19-pertumbuhan-ekonomi-indonesia-2020-bisa-minus-0-4persen/5355838.html.

John Hopkins University and Medicine. 2020. "COVID-19 Map - Johns Hopkins Coronavirus Resource Center.” John Hopkins Coronavirus Resource Center. 2020. https://coronavirus.jhu.edu/map.html.

JPNN. 2019. "Awas, Sudah Ada Kerusuhan Akibat Lockdown Tanpa Cukup Pangan Internasional JPNN.Com.” April 19, 2019. https://www.jpnn.com/news/awas-sudahada-kerusuhan-akibat-lockdown-tanpa-cukup-pangan.

. 2020. "Tiongkok Beri Peringatan Buat Indonesia Yang Berencana Hentikan Impor Nasional JPNN.Com.” February 5, 2020. https://www.jpnn.com/news/tiongkok-beriperingatan-buat-indonesia-yang-berencana-hentikan-impor.

Kementerian Kesehatan Republik Indonesia. 2003. "8 Wilayah/Negara Telah Terjadi Penularan SARS Diantara Masyarakat." 2003. https://www.kemkes.go.id/development/site/jkn/index.php?cid=500\&id=8-wilayahnegara-telah-terjadi-penularan-sars-diantara-masyarakat.html.

Kementrian Luar Negeri Indonesia. 2020. "LANGKAH DAN UPAYA PEMERINTAH INDONESIA DALAM MENANGANI DAN MENGHADAPI VIRUS NOVEL CORONA 2019 (N-COV)." $\quad$ February 2020. https://kemlu.go.id/pretoria/id/news/4771/langkah-dan-upaya-pemerintah-indonesiadalam-menangani-dan-menghadapi-virus-novel-corona-2019-n-cov.

kompas.com. 2020. "Foto: Tren Kasus Covid-19 Meningkat Di Bulan Juni, Ini Alasannya Menurut Ahli Halaman 1." 2020. https://www.kompas.com/tren/image/2020/06/17/200500665/tren-kasus-covid-19meningkat-di-bulan-juni-ini-alasannya-menurut-ahli?page $=1$.

Kompas.com. 2020a. "Dua WNI Yang Positif Virus Corona Tinggal Di Depok Halaman All Kompas.Com." $2020 . \quad$ March 2020. https://nasional.kompas.com/read/2020/03/02/12041761/dua-wni-yang-positif-viruscorona-tinggal-di-depok?page $=$ all. . 2020b. "Jadi Opsi Terakhir, Ini Penjelasan Darurat Sipil Dalam Konteks Bencana." April 1, 2020. https://nasional.kompas.com/read/2020/04/01/10034181/jadi-opsiterakhir-ini-penjelasan-darurat-sipil-dalam-konteks-bencana.

Laosana, Nina A. 2020. “Jakarta's Island Starts Housing Evacuees from World Dream Cruise 
Ship - City - The Jakarta Post." February 28, 2020. https://www.thejakartapost.com/news/2020/02/28/jakartas-island-starts-housingevacuees-from-world-dream-cruise-ship.html.

Ma, Josephine. 2020. "Coronavirus: China's First Confirmed Covid-19 Case Traced Back to November 17 | South China Morning Post." March 20, 2020. https://www.scmp.com/news/china/society/article/3074991/coronavirus-chinas-firstconfirmed-covid-19-case-traced-back.

Mahfud MD. 2020. "Mahfud MD on Twitter: 'ALHAMDULILLAH' 243 WNI Yg Pulang Dr Wuhan Dan Diobservasi 14 Hr Di Natuna Dinyatakan Brsh Dr Corona. Dlm Kelakarnya, Menko Perekonomian Airlangga Bilang "Krn Perizinan Di Indonesia Ber-Belit2 Maka Virus Corona Tak Bs Masuk. Tp Omnibus Law Ttg Perizinan Lapangan Kerja Jalan Trs" (30) Https://T.Co/GQ3QmkP58G" / Twitter."” February 15, 2020. https://twitter.com/mohmahfudmd/status/1228545879885221890.

Maranda, Servio. 2020. "Ma'ruf Amin: Indonesia Terhindar Corona, Berkah Ulama Baca Doa - Nasional Tempo.Co." 2020. https://nasional.tempo.co/read/1312782/maruf-amin-indonesia-terhindar-coronaberkah-ulama-baca-doa.

Martha, Jessica. 2020. "Pemanfaatan Diplomasi Publik Oleh Indonesia Dalam Krisis Covid19." Jurnal Ilmiah Hubungan Internasional -Pacis 7 (April). http://103.36.68.33/index.php/JurnalIlmiahHubunganInternasiona/article/view/3859/2 914.

Muhaemin, Abdul. 2020. "6 Pekan Karantina COVID-19 Berujung Kerusuhan Dan Penjarahan, Seorang Pria Ditembak Mati - Pikiran-Rakyat.Com.” April 24, 2020. https://www.pikiran-rakyat.com/internasional/pr-01371045/6-pekan-karantina-covid19-berujung-kerusuhan-dan-penjarahan-seorang-pria-ditembak-mati.

Prabowo, Dani, Nur Rakhmat Hakim, and Fitria Chusna Farisa. 2020. "UPDATE 14 Juni: Bertambah 857, Kasus Covid-19 Di Indonesia Jadi 38.277.” June 14, 2020. https://nasional.kompas.com/read/2020/06/14/15563851/update-14-juni-bertambah857-kasus-covid-19-di-indonesia-jadi-38277.

Pribadi, Indra Arief. 2020. "Presiden Jokowi Perintahkan Penerapan PSBB Ketat Dan Efektif ANTARA Jateng." May 4, 2020. https://jateng.antaranews.com/berita/308271/presiden-jokowi-perintahkan-penerapanpsbb-ketat-dan-efektif.

Purwanto, Agus, Rudy Pramono, Masduki Asbari, Priyono Budi Santoso, Laksmi Mayesti Wijayanti, Chi Hyun Choi, and Ratna Setyowati Putri. 2020. "Studi Eksploratif Dampak Pandemi COVID-19 Terhadap Proses Pembelajaran Online Di Sekolah Dasar." EduPsyCouns: Journal of Education, Psychology and Counseling 2 (1): 1-12. https://ummaspul.e-journal.id/Edupsycouns/article/view/397.

Ramdhan, Adhitya. 2020. "Hadapi Covid-19, Negara-Negara Saling Menguatkan Kompas.Id.” April 5, 2020. https://kompas.id/baca/internasional/2020/04/05/negaranegara-saling-memperkuat/.

Redaksi WE Online. 2020. "Virus Corona Makin Ganas, Menkes Bilang: Enjoy Aja!" January 27, 2020. https://www.wartaekonomi.co.id/read268664/virus-corona-makinganas-menkes-bilang-enjoy-aja.

RMCO. 2020. “Antisipasi Corona, Dubes Gary Quinlan Ditarik Pulang Ke Australia.” April 10, 2020. https://rmco.id/baca-berita/internasional/32317/antisipasi-corona-dubesgary-quinlan-ditarik-pulang-ke-australia.

Rohman, Taufiqur. 2020. "Ibadah Haji 2020 Ditangguhkan, Ternyata Pernah Terjadi Sebelumnya." 2020. https://phinemo.com/ibadah-haji-2020-ditangguhkan-ternyata- 
pernah-terjadi-sebelumnya/.

Saubani, Andri. 2020. "Kelakar Menhub: Kita Kebal Corona Karena Doyan Nasi Kucing | Republika Online." $\quad$ February 17, 2020. https://republika.co.id/berita/q5ul4k409/kelakar-menhub-kita-kebal-corona-karenadoyan-nasi-kucing.

Sutrisno, Debbie. 2020. "Ridwan Kamil Tetapkan Darurat Bencana Penyebaran COVID-19 Di Jabar.” March 21, 2020. https://jabar.idntimes.com/news/jabar/debbiesutrisno/ridwan-kamil-tetapkan-darurat-bencana-penyebaran-covid-19-di-jabar/1.

Taher, Andrian Pratama. 2020. "Jokowi Ajak BIN Tangani Corona \& Tunjuk BNPB Kepalai Gugus Tugas - Tirto.ID.” March 13, 2020. https://tirto.id/jokowi-ajak-bin-tanganicorona-tunjuk-bnpb-kepalai-gugus-tugas-eEPZ.

tirto. 2020. "Daftar Negara Yang Bantu Indonesia Tangani Corona COVID-19 - Tirto.ID." April 7, 2020. https://tirto.id/daftar-negara-yang-bantu-indonesia-tangani-coronacovid-19-eLzV.

Tribun News. 2020. "Indonesia Bersih Dari Virus Corona, Ali Ngabalin: Covid-19 Tidak Berkembang Kuat Di Negara Tropis - Tribunnews.Com.” 2020. https://www.tribunnews.com/nasional/2020/02/29/indonesia-bersih-dari-virus-coronaali-ngabalin-covid-19-tidak-berkembang-kuat-di-negara-tropis.

Tribunnews Mataram. n.d. "POPULER Grafik Kasus Pasien Virus Corona Masih Naik Turun, Ahli Sebut Ada Penularan Saat Lebaran - Halaman All - Tribun Mataram.” Accessed June 20, 2020. https://mataram.tribunnews.com/amp/2020/06/10/populer-grafikkasus-pasien-virus-corona-masih-naik-turun-ahli-sebut-ada-penularan-saatlebaran?page $=$ all.

Utomo, Ardi Priyatno. 2020. "Lockdown Virus Corona Di Italia, Masyarakat Resah Dan Kerusuhan Sosial Meningkat Halaman All - Kompas.Com.” 2020. 2020. https://www.kompas.com/global/read/2020/03/29/164330670/lockdown-virus-coronadi-italia-masyarakat-resah-dan-kerusuhan-sosial?page=all.

Wareza, Monica. 2020. "Cegah Penularan Corona, Polisi Bubarkan Keramaian." April 4, 2020. https://www.cnbcindonesia.com/news/20200404171430-4-149800/cegahpenularan-corona-polisi-bubarkan-keramaian. 